\title{
Chromosome numbers and meiotic behavior of some Paspalum accessions
}

\author{
Eleniza de Victor Adamowski ${ }^{1}$, Maria Suely Pagliarini ${ }^{2}$, Andréa Beatriz Mendes Bonato ${ }^{2}$, Luiz Alberto \\ Rocha Batista $^{3}$ and José Francisco Montenegro Valls ${ }^{4}$ \\ ${ }^{1}$ Universidade Paranaense, Umuarama, PR, Brazil. \\ ${ }^{2}$ Universidade Estadual de Maringá, Departamento de Genética e Biologia Celular, Maringá, PR, Brazil. \\ ${ }^{3}$ Centro de Pesquisa de Pecuária do Sudeste, Embrapa, São Carlos, SP, Brazil. \\ ${ }^{4}$ Embrapa/Cenargen, Brasília, DF, Brazil.
}

\begin{abstract}
Chromosome number and meiotic behavior were evaluated in 36 Brazilian accessions of the grass Paspalum (which had never previously been analyzed) to determinate which accessions might be useful in interspecific hybridizations. The analysis showed that one accession of Paspalum coryphaeum was diploid $(2 n=2 x=20)$ and one accession of Paspalum conspersum hexaploid $(2 n=6 x=60)$, the remaining 34 accessions being tetraploid $(2 n=4 x=40)$. The pairing configuration was typical for the ploidy level i.e. in the diploid, chromosomes paired as 10 bivalents, in tetraploids as bi-, tri- and quadrivalents, and in hexaploid as 30 bivalents. A low frequency of meiotic abnormalities (less than 10\%) was observed in the diploid, hexaploid and some tetraploid accessions, although the majority of tetraploid accessions showed a high frequency of meiotic irregularities. The use of accessions with a low frequency of meiotic abnormalities in breeding programs is discussed.
\end{abstract}

Key words: Paspalum, forage grass, chromosome numbers, meiotic behavior.

Received: December 23, 2004; Accepted: May 4, 2005.

\section{Introduction}

The genus Paspalum (L.), one of the most economically important grass genera of the Paniceae tribe, includes approximately 330 species distributed in tropical and subtropical regions of America, with a few taxa growing in the Old World (Denham et al., 2002). A large number of Paspalum species provide excellent grazing in native grasslands of the warm regions of South America (Bonilha and Quarín, 1997) and several members of the genus are also used as turf grass and for ornamental purposes (Burson and Bennett, 1971). Several species occur in the various Brazilian ecosystems, however only a few native species (especially those belonging to the Dilatata, Notata and Plicatula groups) have been cultivated as forage (Quarín et al., 1996). Although great progress has been made in cytological studies of members of the genus, little or no information is available for a large number of members of species and accessions held in herbariums. However, approximately $80 \%$ of the Paspalum species which have been cytologically investigated are polyploids, or have polyploid

Send correspondence to Dr. Maria Suely Pagliarini. Universidade Estadual de Maringá, Departamento de Genética e Biologia Celular, 87020-900 Maringá, Paraná, Brazil. E-mail: mspagliarini@ uem.br. races, with about $50 \%$ of these polyploids being tetraploids of which most are apomictic (Quarín, 1992). This type of cytology complicates breeding programs.

During the last three decades, several collection trips have been undertaken by Embrapa Cenargen throughout Brazil, Paraguay, and Argentina to establish a base Paspalum collection. As a result, a germplasm collection comprising more than 1500 accessions of different Paspalum species is available at Embrapa Cenargen (Brasilia, DF), with a small part of this collection being duplicated at the Institute of Botany (IBONE) at Corrientes, Argentina (Quarín et al., 1997). Part of the Cenargen Paspalum germplasm collection was allocated to the Embrapa/Centro de Pesquisa de Pecuária do Sudeste (CPPSE), São Carlos, São Paulo state, Brazil) where the agronomic aspects of 216 Paspalum accessions (known as the CPPSE collection) are currently being evaluated (Batista et al., $1995)$ with the aim of selecting accessions for intra- and interspecific crosses to be used for obtaining new varieties.

Cytological analyses have been performed on more than 80 accessions from the CPPSE collection (Freitas et al., 1997; Takayama et al., 1998; Adamowski et al., 1998, 2000; Pagliarini et al., 1998, 1999, 2000, 2001) and the data presented in the present paper extends this study to a further 36 previously unanalyzed Paspalum accessions, including 
$P$. notatum Fluegge, $P$. compressifolium Swallen, $P$. usterii Hack., $P$. plicatulum Michx., $P$. atratum Swallen, $P$. coryphaeum Trin., P. lividum, P. rhodopedum L. B. Smith $\&$ Wasshausen, $P$. limbatum Henrard, P. conspersum Schrad and unidentified accessions belonging to the Plicatula group. The Plicatula group is an unofficial taxonomic rank created by Chase (1929) to group species related to $P$. plicatulum, this group having its geographical center of variation in central and western Brazil, eastern Bolivia and Paraguay (Quarín et al., 1997). Of the informal taxonomic groups into which the genus Paspalum has been subdivided (Chase, 1929), the Plicatula group is of the greatest agronomic interest because it encompasses a wide variation of forms and species, several of which are well accepted by cattle (Quarín et al., 1997). Since knowledge of the cytology and reproductive behavior of a species is es- sential for interspecific hybridization programs the aim of this research was to investigate the chromosome number and meiotic behavior of 36 Embrapa CPPSE germplasm accessions which had not before been analyzed.

\section{Material and Methods}

Cytogenetic studies were carried out on 36 accessions from the Embrapa CPPSE Paspalum collection, these accessions having been collected from several different regions of Brazil (Table 1). Of the 36 accessions analyzed, 18 Plicatula group accessions were not identified to species level.

Young inflorescences were collected at Embrapa CPPSE and fixed in 3:1 ethyl alcohol:acetic acid for $24 \mathrm{~h}$ at room temperature and then transferred to $70 \%(\mathrm{v} / \mathrm{v})$ aque-

Table 1 - Species investigated in the present study with their accession numbers and collection site details.

\begin{tabular}{|c|c|c|c|c|c|}
\hline Species & Accession numbers & Collection sites* & Latitude (South) & Longitude (West) & Altitude (m) \\
\hline \multicolumn{6}{|l|}{ Livida group } \\
\hline P. lividum & BRA-006378 & São Gabriel, RS & $30^{\circ} 19^{\prime}$ & $54^{\circ} 16^{\prime}$ & 140 \\
\hline \multicolumn{6}{|l|}{ Malacophylla group } \\
\hline P. usterii & BRA-022624 & & & & \\
\hline \multicolumn{6}{|l|}{ Notata group } \\
\hline P. notatum & BRA-006513 & Uruguaiana, RS & $29^{\circ} 33^{\prime}$ & $56^{\circ} 47^{\prime}$ & 90 \\
\hline P. notatum & BRA-008028 & Lages, SC & & & - \\
\hline \multicolumn{6}{|l|}{ Plicatula group } \\
\hline P. compressifolum & BRA-013102 & Balsa Nova, PR & $25^{\circ} 27^{\prime}$ & $49^{\circ} 38^{\prime}$ & 1160 \\
\hline P. compressifolum & BRA-011282 & Passo Fundo, Rs & $28^{\circ} 14^{\prime}$ & $52^{\circ} 18^{\prime}$ & 680 \\
\hline P. compressifoum & BRA-009105 & Guaíba, RS & $30^{\circ} 06^{\prime}$ & $51^{\circ} 19^{\prime}$ & 30 \\
\hline P. compressifolum & BRA-011304 & Passo Fundo, RS & $28^{\circ} 14^{\prime}$ & $52^{\circ} 18^{\prime}$ & 680 \\
\hline$P$. atratum & BRA-009661 & Aquidauana, MS & $20^{\circ} 22^{\prime}$ & $55^{\circ} 59^{\prime}$ & 180 \\
\hline P. plicatulum & BRA-008940 & São Gabriel, RS & $30^{\circ} 15^{\prime}$ & $54^{\circ} 32^{\prime}$ & 160 \\
\hline P. plicatulum & BRA-006157 & São Gabriel, RS & $30^{\circ} 24^{\prime}$ & $54^{\circ} 19^{\prime}$ & 360 \\
\hline P. plicatulum & BRA-009784 & Rio Grande, RS & $32^{\circ} 07^{\prime}$ & $52^{\circ} 21^{\prime}$ & 15 \\
\hline P. rhodopedum & BRA-006602 & Santo Angelo, RS & $28^{\circ} 24^{\prime}$ & $54^{\circ} 18^{\prime}$ & 260 \\
\hline P. rhodopedum & BRA-006670 & Passo Fundo, RS & $28^{\circ} 14^{\prime}$ & $52^{\circ} 18^{\prime}$ & 690 \\
\hline P. limbatum & BRA-012530 & Ribas do Rio Pardo, MS & $20^{\circ} 25^{\prime}$ & $53^{\circ} 39^{\prime}$ & 390 \\
\hline P. limbatum & BRA-009008 & Campo Grande, MS & $20^{\circ} 25^{\prime}$ & $54^{\circ} 40^{\prime}$ & 500 \\
\hline Paspalum sp & BRA-008486 & Planaltina, DF & $15^{\circ} 30^{\prime}$ & $47^{\circ} 45^{\prime}$ & 1000 \\
\hline Paspalum sp & BRA-008630 & Lages, SC & $27^{\circ} 57^{\prime}$ & $50^{\circ} 27^{\prime}$ & 980 \\
\hline Paspalum sp & BRA-008648 & Lages, SC & $27^{\circ} 57^{\prime}$ & $50^{\circ} 27^{\prime}$ & 980 \\
\hline Paspalum sp & BRA-008656 & Lages, SC & $27^{\circ} 57^{\prime}$ & $50^{\circ} 27^{\prime}$ & 950 \\
\hline Paspalum sp & BRA-008672 & Vacaria, SC & $28^{\circ} 20^{\prime}$ & $50^{\circ} 18^{\prime}$ & 980 \\
\hline Paspalum sp & BRA-009393 & Ji-Paraná, RO & $10^{\circ} 53^{\prime}$ & $61^{\circ} 57^{\prime}$ & 170 \\
\hline Paspalum sp & BRA-010243 & Montes Claros, Ms & $16^{\circ} 30^{\prime}$ & $43^{\circ} 50^{\prime}$ & 700 \\
\hline Paspalum sp & BRA-011053 & Sto Antônio das Missões, RS & $28^{\circ} 30^{\prime}$ & $55^{\circ} 14^{\prime}$ & 120 \\
\hline Paspalum $s p$ & BRA-011266 & Passo Fundo, RS & $28^{\circ} 15^{\prime}$ & $51^{\circ} 52^{\prime}$ & 630 \\
\hline Paspalum sp & BRA-012521 & Três Lagoas, MS & $20^{\circ} 46^{\prime}$ & $50^{\circ} 40^{\prime}$ & 400 \\
\hline
\end{tabular}


Table 1 (cont.)

\begin{tabular}{|c|c|c|c|c|c|}
\hline Species & Accession numbers & Collection sites* & Latitude (South) & Longitude (West) & Altitude (m) \\
\hline Paspalum $s p$ & BRA-012751 & Caarapó, MS & $22^{\circ} 25^{\prime}$ & $54^{\circ} 41^{\prime}$ & 320 \\
\hline Paspalum sp & BRA-013404 & Balsa Nova, PR & $25^{\circ} 27^{\prime}$ & $49^{\circ} 38^{\prime}$ & 1100 \\
\hline Paspalum sp & BRA-013609 & Ponta Grossa, PR & $25^{\circ} 08^{\prime}$ & $50^{\circ} 09^{\prime}$ & 960 \\
\hline Paspalum sp & BRA-014770 & Unaí, MG & $16^{\circ} 25^{\prime}$ & $46^{\circ} 50^{\prime}$ & 620 \\
\hline Paspalum sp & BRA-009636 & Miranda, MS & $20^{\circ} 18^{\prime}$ & $56^{\circ} 25^{\prime}$ & 160 \\
\hline Paspalum sp & BRA-013951 & Ponta Grossa, PR & $25^{\circ} 08^{\prime}$ & $50^{\circ} 09^{\prime}$ & 820 \\
\hline Paspalum sp & BRA-008681 & Lages, SC & $27^{\circ} 57^{\prime}$ & $50^{\circ} 27^{\prime}$ & 900 \\
\hline Paspalum $s p$ & BRA-011517 & Bom Jesus, RS & $28^{\circ} 40^{\prime}$ & $50^{\circ} 15^{\prime}$ & 1220 \\
\hline \multicolumn{6}{|c|}{ Quadrifaria group } \\
\hline P. coryphaeum & BRA-000841 & Anaurilândia, MS & $22^{\circ} 25^{\prime}$ & $50^{\circ} 35^{\prime}$ & 200 \\
\hline \multicolumn{6}{|l|}{ Virgata group } \\
\hline P. conspersum & BRA-010260 & Miranda, RS & $20^{\circ} 18^{\prime}$ & $56^{\circ} 25^{\prime}$ & 160 \\
\hline
\end{tabular}

*The two-letter code after the collection site refers to the Brazilian state, DF = Distrito Federal, MS = Mato Grosso do Sul, $\mathrm{PR}=$ Paraná, RG = Rio Grande do Sul, SC = Santa Catarina.

ous alcohol and stored in a freezer until needed. Microsporocytes (PMCs) were prepared from the inflorescences by squashing and staining with $1 \%$ propionic carmine. The chromosome number and the pairing configuration were determined in 20 meiocytes at diakinesis, and the meiotic behavior determined in more than 2000 microsporocytes up to this phase to the end of meiosis with a similar number of cells in each phase.

\section{Results and Discussion}

Of the 36 CPPSE accessions examined by us, one was diploid $(2 n=2 x=20), 34$ were tetraploid $(2 n=4 x=40)$ and one was hexaploid $(2 n=60)$ (Table 2$)$, however, the chromosome numbers of specific species were not always in agreement with previously published reports. The chromo- some number of $P$. coryphaeum was reported by Burson (1975) as $2 \mathrm{n}=40$ but we found $P$. coryphaeum BRA000841 to be $2 \mathrm{n}=20$. Snyder (1953) reported that $P$. lividum was $2 \mathrm{n}=70$ although other authors (Gould, 1958, 1968; Reeder, 1967; Burson and Bennett, 1971; Pagliarini et al., 2001) reported that it was $2 \mathrm{n}=40$, the same chromosome number we found for P. lividum BRA-006378. Chromosome numbers of $2 \mathrm{n}=20$ and $2 \mathrm{n}=40$ have been reported for P. notatum by various authors (Burton, 1940; Forbes and Burton, 1961; Fernandes et al., 1974; Mehra and Chaudhary, 1981; Pozzobon and Valls, 1997; Pagliarini et al., 2001), while we found that the two $P$. notatum accessions (BRA-006513 and BRA-008028) examined were both $2 \mathrm{n}=40$. The chromosome number of $P$. conspersum has been reported as both $2 n=40$ and $2 n=60$

Table 2 - Chromosome numbers and meiotic chromosome associations at diakinesis.

\begin{tabular}{|c|c|c|c|c|c|c|c|c|c|c|c|}
\hline \multirow[t]{3}{*}{ Paspalum species } & \multirow{3}{*}{$\begin{array}{l}\text { Accession } \\
\text { number }\end{array}$} & \multirow[t]{3}{*}{$2 \mathrm{n}$} & \multirow{3}{*}{$\begin{array}{l}\text { N. of } \\
\text { PMCs }\end{array}$} & \multicolumn{8}{|c|}{ Chromosome associations } \\
\hline & & & & \multicolumn{4}{|c|}{ Range } & \multicolumn{4}{|c|}{ Average per cell } \\
\hline & & & & I & II & III & IV & $\mathrm{I}$ & II & III & IV \\
\hline P. coryphaeum & BRA-000841 & 20 & 20 & - & 10 & - & - & - & 20.0 & - & - \\
\hline P. lividum & BRA-006378 & 40 & & & & & & & & & \\
\hline P. notatum & BRA-006513 & 40 & & & & & & & & & \\
\hline P. notatum & BRA-008028 & 40 & 20 & $(0-4)$ & $(8-18)$ & $(0-2)$ & $(1-5)$ & 1.10 & 13.55 & 1.40 & 2.15 \\
\hline P. conspersum & BRA-010260 & 60 & 20 & - & 30 & - & - & - & 30.0 & - & - \\
\hline P. usterii & BRA-011355 & 40 & 20 & $(0-1)$ & $(16-20)$ & $(0-1)$ & $(0-3)$ & 0.10 & 18.65 & 0.10 & 0.55 \\
\hline P. compressifolium & BRA-013102 & 40 & 20 & $(0-3)$ & $(4-16)$ & $(0-1)$ & $(2-5)$ & 0.25 & 11.35 & 0.15 & 4.15 \\
\hline P. compressifolium & BRA-011282 & 40 & 20 & $(0-2)$ & $(5-20)$ & $(0-2)$ & $(0-6)$ & 0.30 & 14.80 & 0.20 & 2.20 \\
\hline P. compressifolium & BRA-009105 & 40 & 20 & $(0-4)$ & $(8-20)$ & $(0-1)$ & $(0-5)$ & 0.60 & 16.45 & 0.10 & 1.45 \\
\hline P. compressifolium & BRA-011304 & 40 & 23 & $(0-4)$ & $(10-20)$ & - & $(0-5)$ & 0.87 & 18.00 & - & 0.52 \\
\hline
\end{tabular}


Table 2 (cont.)

\begin{tabular}{|c|c|c|c|c|c|c|c|c|c|c|c|}
\hline \multirow[t]{3}{*}{ Paspalum species } & \multirow{3}{*}{$\begin{array}{l}\text { Accession } \\
\text { number }\end{array}$} & \multirow[t]{3}{*}{$2 n$} & \multirow{3}{*}{$\begin{array}{l}\text { N. of } \\
\text { PMCs }\end{array}$} & \multicolumn{8}{|c|}{ Chromosome associations } \\
\hline & & & & \multicolumn{4}{|c|}{ Range } & \multicolumn{4}{|c|}{ Average per cell } \\
\hline & & & & I & II & III & IV & I & II & III & IV \\
\hline P. atratum & BRA-009661 & 40 & & & & & & & & & \\
\hline P. plicatulum & BRA-008940 & 40 & 20 & $(0-10)$ & $(2-18)$ & $(0-4)$ & $(0-9)$ & 2.35 & 8.95 & 0.95 & 4.20 \\
\hline P. plicatulum & BRA-006157 & 40 & 20 & $(0-20)$ & $(8-20)$ & $(0-4)$ & $(0-3)$ & 3.20 & 15.50 & 0.80 & 0.90 \\
\hline P. plicatulum & BRA-009784 & 40 & 20 & $(0-2)$ & $(9-16)$ & $(0-2)$ & $(2-5)$ & 0.50 & 13.25 & 0.20 & 3.10 \\
\hline P. rhodopedum & BRA-006602 & 40 & 20 & $(0-4)$ & $(6-20)$ & $(0-2)$ & $(0-7)$ & 0.85 & 13.70 & 0.15 & 2.80 \\
\hline P. rhodopedum & BRA-006670 & 40 & 20 & $(0-4)$ & $(10-18)$ & $(0-1)$ & $(1-4)$ & 1.9 & 14.25 & 0.20 & 2.25 \\
\hline P. limbatum & BRA-012530 & 40 & 21 & $(0-6)$ & $(2-20)$ & $(0-3)$ & $(0-9)$ & 0.62 & 9.43 & 0.19 & 4.71 \\
\hline P. limbatum & BRA-009008 & 40 & 20 & $(0-1)$ & $(4-14)$ & $(0-1)$ & $(3-8)$ & 0.10 & 10.30 & 0.10 & 5.15 \\
\hline Paspalum sp & BRA-008486 & 40 & 20 & $(0-2)$ & $(12-17)$ & - & $(1-2)$ & 0.90 & 15.70 & - & 2.05 \\
\hline Paspalum sp & BRA-008630 & 40 & 20 & $(0-2)$ & $(9-18)$ & $(0-1)$ & $(1-5)$ & 0.60 & 16.00 & 0.20 & 1.70 \\
\hline Paspalum $s p$ & BRA-008648 & 40 & 20 & $(0-6)$ & $(5-17)$ & $(0-2)$ & $(0-7)$ & 1.40 & 11.75 & 0.30 & 3.65 \\
\hline Paspalum sp & BRA-008656 & 40 & 22 & $(0-5)$ & $(6-20)$ & $(0-1)$ & $(0-6)$ & 1.27 & 13.41 & 0.27 & 2.73 \\
\hline Paspalum sp & BRA-008672 & 40 & 21 & $(0-6)$ & $(4-20)$ & $(0-4)$ & $(0-8)$ & 1.00 & 15.24 & 0.24 & 2.00 \\
\hline Paspalum sp & BRA-009393 & 40 & 40 & $(0-4)$ & $(4-20)$ & $(0-3)$ & $(0-8)$ & 0.40 & 12.25 & 0.60 & 3.55 \\
\hline Paspalum sp & BRA-010243 & 40 & 20 & $(0-16)$ & $(0-20)$ & $(0-3)$ & $(0-8)$ & 3.60 & 12.20 & 0.60 & 2.35 \\
\hline Paspalum sp & BRA-011053 & 40 & 21 & $(0-10)$ & $(6-17)$ & $(0-2)$ & $(0-6)$ & 1.76 & 12.05 & 0.14 & 3.33 \\
\hline Paspalum sp & BRA-011266 & 40 & 21 & $(0-12)$ & $(10-20)$ & $(0-3)$ & $(0-5)$ & 1.14 & 13.81 & 0.48 & 2.43 \\
\hline Paspalum sp & BRA-012521 & 40 & 21 & $(0-6)$ & $(10-20)$ & $(0-3)$ & $(0-5)$ & 1.86 & 14.33 & 0.52 & 1.43 \\
\hline Paspalum sp & BRA-012751 & 40 & 25 & $(0-32)$ & $(4-18)$ & $(0-5)$ & $(0-6)$ & 6.52 & 11.96 & 0.52 & 2.00 \\
\hline Paspalum sp & BRA-013404 & 40 & 20 & $(0-5)$ & $(9-19)$ & $(0-2)$ & $(0-4)$ & 1.20 & 15.50 & 0.60 & 1.50 \\
\hline Paspalum sp & BRA-013609 & 40 & 20 & $(0-10)$ & $(2-16)$ & $(0-3)$ & $(0-9)$ & 3.20 & 11.30 & 0.60 & 3.00 \\
\hline Paspalum sp & BRA-014770 & 40 & 20 & $(0-2)$ & $(10-19)$ & $(0-1)$ & $(2-4)$ & 0.30 & 12.90 & 0.20 & 3.40 \\
\hline Paspalum sp & BRA-009636 & 40 & 20 & $(0-2)$ & $(12-20)$ & - & $(0-4)$ & 0.60 & 16.50 & - & 1.60 \\
\hline Paspalum sp & BRA-013951 & 40 & 21 & $(0-5)$ & $(10-16)$ & $(0-1)$ & $(1-5)$ & 0.61 & 16.76 & 0.09 & 2.76 \\
\hline Paspalum sp & BRA-008681 & 40 & 21 & $(0-2)$ & $(8-18)$ & $(0-1)$ & $(1-6)$ & 0.38 & 14.90 & 0.09 & 2.38 \\
\hline Paspalum sp & BRA-011517 & 40 & 20 & $(0-3)$ & $(6-17)$ & $(0-1)$ & $(1-7)$ & 0.45 & 10.60 & 0.25 & 4.40 \\
\hline
\end{tabular}

(Fernandes et al., 1974; Quarín, 1977; Quarín and Hanna, 1980; Pagliarini et al., 2001), and we found P. conspersum BRA-010260 to be $2 \mathrm{n}=60$. Chromosome numbers of $2 \mathrm{n}=$ $20,2 \mathrm{n}=40$ and $2 \mathrm{n}=60$ have been reported for $P$. plicatulum (Brown, 1950; Nuñez, 1952; Reeder, 1967; Burson and Bennett, 1971; Davidse and Pohl, 1972; Takayama et al., 1998; Pagliarini et al., 2001), but our three $P$. plicatulum accessions (BRA-008940, BRA-006157, BRA-009784) were all 2n=40. Quarín et al. (1997) and Takayama et al. (1998) both reported that the chromosome number of $P$. atratum was $2 \mathrm{n}=40$, the same number which we attributed to $P$. atratum BRA-009661. The chromosome number of $P$. compressifolium has been variously reported as being $2 \mathrm{n}=20,2 \mathrm{n}=40$ and $2 \mathrm{n}=60$ (Honfi et al., 1990; Quarín et al., 1996; Takayama et al., 1998; Pagliarini et al., 2001), while we found that our four $P$. compressifolium accessions (BRA-013102, BRA-011282, BRA-009105, BRA-011304) were all $2 \mathrm{n}=40$. No data was found in the literature regarding the chromosome number of $P$. usterii, which for our accession (BRA-011355) was $2 n=40$. Our data once again reinforces the opinion that polyploidy is predominant in the genus Paspalum and that tetraploidy is the most prevalent form. However, in our group of 36 accessions, 34 (94\%) were tetraploid, much higher than the 50\% reported by Quarín (1992).

The pairing configuration at diakinesis varied among accessions with the same ploidy level (Table 2). In the diploid $P$. coryphaeum accession only bivalents were recorded (Figure 1a) but among the tetraploid accessions the pairing behavior was irregular and diverse, with uni-, bi-, tri- and quadrivalents being observed (Figure 1b). In general, tetraploid accessions showed a predominance of bivalent chromosome associations. In three accessions (BRA-009661, BRA-006378, and BRA-006513), diakinesis was not adequate for analysis of chromosome pairing. For the diploid and tetraploid levels of ploidy, the behavior of chromosome 


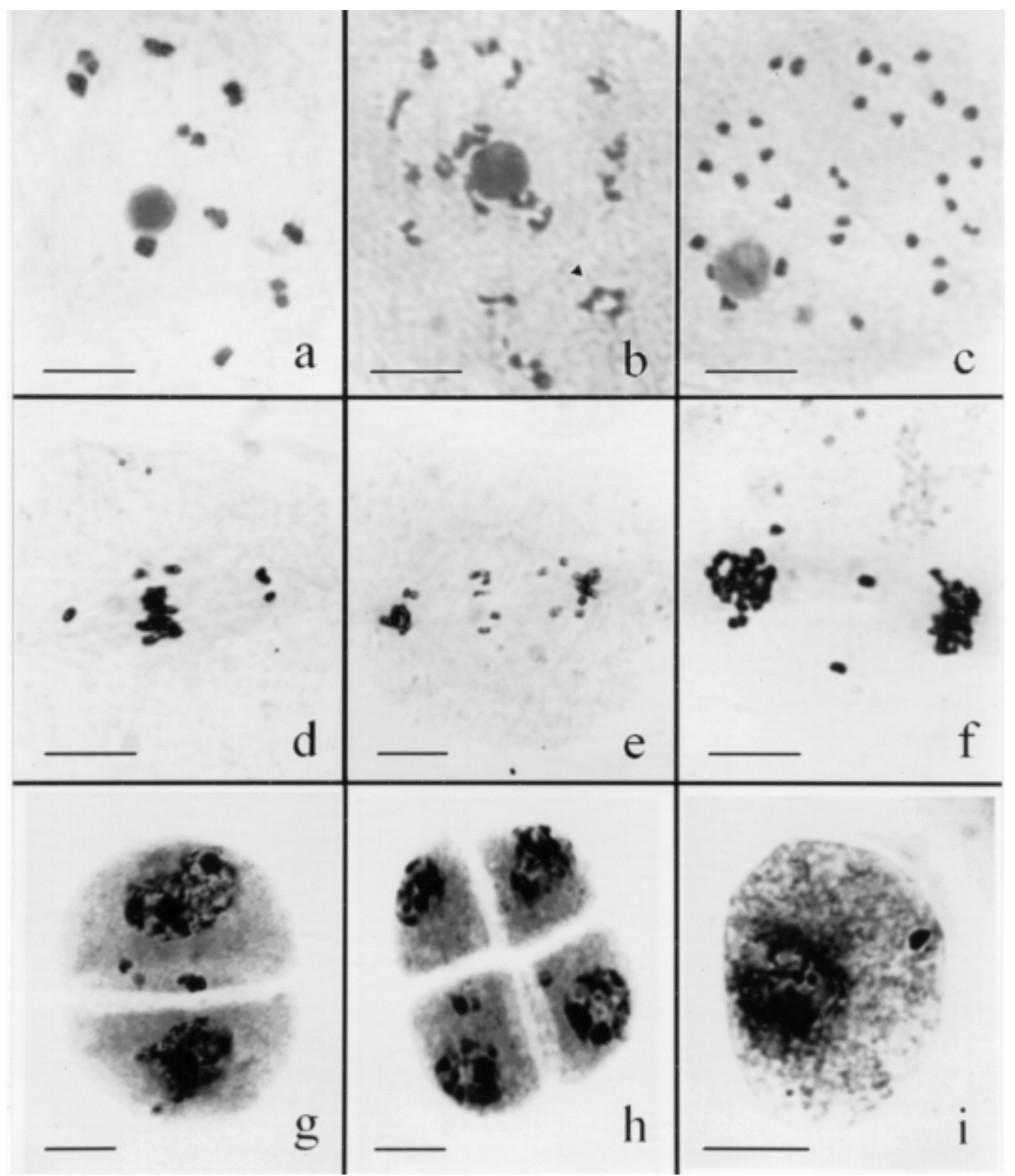

Figure 1 - Meiotic behavior in different Paspalum cytotypes. a) Diakinesis in the diploid accession of $P$. coryphaeum showing 10 II. b) Diakinesis in tetraploid accession showing 18 II and 1 IV (arrowhead). c) Diakinesis in the hexaploid accession of P. conspersum with 30 II. d) Metaphase I in tetraploid accession showing precocious chromosome migration to the poles. e) Anaphase I in tetraploid accession showing laggards. f) Early telophase I in tetraploid accession with micronuclei. f) Prophase II with micronuclei. g) Tetrad with micronuclei. h) Microspore with micronuclei. Scale bar $=1 \mu \mathrm{m}$.

association was in agreement with previous reports on the same or other Paspalum species (Burson and Bennett, 1971; Quarín et al., 1996; Takayama et al., 1998; Pagliarini et al., 2001). For the hexaploid accession of P. conspersum, chromosomes paired as bivalents (Figure 1c). Hexaploid accessions reported in literature presented chromosome association including uni-, bi-, tri- and quadrivalents (Burson and Bennett, 1971; Quarín and Burson, 1991; Takayama et al., 1998; Pagliarini et al., 2001).

The tetraploid accessions could have been produced either by chromosome duplication or by interspecific hybrid- ization followed by duplication. The low frequency of quadrivalents in tetraploid accessions reported in several Paspalum species has been interpreted as resulting from segmental allopolyploidy (Burson and Bennett, 1971; Norrmann et al., 1989; Quarín et al., 1996; Takayama et al., 1998; Pagliarini et al., 2001). Although low multivalent frequency is an argument frequently used in advocating segmental allopolyploidy, Sybenga (1996a) pointed out that this character is not necessarily a reliable indication of limited pairing affinity, and thus of homology, because even true autopolyploids may form quadrivalents with frequencies 
substantially lower than theoretically possible. Quarín (1992) has proposed that at least in apomictic Panicoid grasses, polyploidy is a condition for apomixis and that apomixis is associated with autoploidy rather than alloploidy. Evidence for autoploidy was provided by Quarín et al. (1998) in a tetraploid accession of P. rufum Ness.

It has been hypothesized that hexaploid accessions are produced by hybridization (Katayama and Ikeda, 1975) or the fertilization of unreduced eggs in apomictic tetraploid forms (Quarín and Burson, 1991). Hexaploidy in Paspalum, with chromosomes pairing as 30 bivalents during meiosis, has been reported in the Uruguayan biotype of P. dilatatum Poiret (Burson et al., 1991), this biotype having I and $\mathrm{J}$ genomes as well as an unidentified third genome (designated X) giving it the genomic form IIJJXX (Burson, 1991). The meiotic behavior at diakinesis in the hexaploid accession of $P$. conspersum, with chromosomes pairing only as bivalents, suggest that it resulted from hybridization followed by chromosome duplication to produce an amphidiploid with a diploid-like meiotic process.

Our analysis of meiotic behavior showed that it was compatible with ploidy level and the status of chromosome pairing (Table 3). In the diploid accession of $P$. coryphaeum, with chromosomes pairing as bivalents (10 II), a low frequency of abnormalities was recorded in all meiotic phases, resulting in a high frequency of normal tetrads $(99.6 \%)$. In all accessions analyzed the abnormalities recorded were related to irregular chromosome segregation and resulted from precocious chiasmata termination. In the hexaploid accession of $P$. conspersum, which presented a diploid-like meiotic process, with chromosomes pairing as 30 bivalents, microsporogenesis was initially irregular. Asynchrony in chiasma termination among bivalents in this accession led to precocious chromosome migration to the poles in metaphase I and laggards in anaphase I. However, the majority of such chromosomes were included in the telophase I nuclei and the second meiotic division presented a low frequency of meiotic irregularities. For tetraploid accessions, however, meiotic behavior varied among accessions, with the percentage of abnormal tetrad ranging from $0.6 \%$ in the accession BRA-009008 to $88.5 \%$ in BRA-01252 and with only three presenting less than $10 \%$ of abnormal tetrads. Except for a few other tetraploid accessions, the frequency of abnormalities during meiosis leading to abnormal tetrads was very high. In all accessions analyzed, the meiotic abnormalities were related to irregular chromosome segregation during both meiotic divisions, such as precocious chromosome migration to the poles during the metaphases (Figure 1d) and anaphase laggards (Figure 1e), resulting in micronuclei in the telophases (Figure 1f). Unbalanced gametes generated from these irregularities could compromise pollen fertility.

Some Paspalum species, such as some biotypes of $P$. dilatatum (Venuto et al., 2003), P. simplex Morong ex Britton (Urbani et al., 2002), P. atratum (Quarín et al.,
1997), P. compressifolium (Quarín et al., 1996) and $P$. notatum (Tischler and Burson, 1995) provide excellent pasture in cattle production systems in several countries, including the Brazil, Thailand and the USA. The Paspalum cultivars used are generally selected based on natural genetic variability, because of which any lack of diversity represents an obvious risk to the ecosystem as well as to cattle production. Therefore rational exploitation of the diversity present in the germplasm, especially for species with good forage value, is of fundamental importance in maintaining diversity in the field. New cultivars are urgently needed and intra- and interspecific hybridizations are desirable as means of introgressing genes but certain difficulties, including differences in ploidy level among accessions and reproduction by apomixis, have delayed the development of new hybrids.

Regardless of an adequate germplasm base, breeding programs demand a knowledge of the mode of reproduction, chromosome number and meiotic behavior to direct the crosses. Apomixis has been widely recognized as a common method of reproduction in the Paspalum. In general, diploids are sexual and most polyploids are apomictic (Quarín and Burson, 1991), however, some polyploids reproduce sexually and many apomictics are facultative (Burson, 1997). Sexual reproduction in tetraploids has invariably been reported to occur in individuals with normal meiosis (Burson and Bennett, 1971; Quarín and Normann, 1987). Despite identifying promising accessions, the Paspalum breeding program in effect at Embrapa CPPSE depends on sexual accessions to act as female genitors in hybridizations. Tetraploid apomictic accessions with nearly regular meiosis, such as were found in some accessions in the present study, could be used as male genitors. Thus, wide cytological screening is a pre-requisite in Paspalum breeding programs. Our investigation revealed that among the 36 accessions evaluated, the diploid $P$. coryphaeum accession BRA-000841 could be used as the sexual female genitor and four tetraploid accessions $(P$. notatum BRA-006513, $P$. limbatum BRA-009008, $P$. rhodopedum BRA-006602 and Paspalum sp BRA-008630), with less than $10 \%$ of abnormal tetrads might have a potential for use in an interspecific hybridization program as male genitors. Our cytogenetic characterization of 36 CPPSE accessions has increased the possibilities of crosses between the Paspalum accessions available at Embrapa CPPSE because in the first analysis of 52 CPPSE accessions only tetra- and hexaploid cytotypes were found (Freitas et al., 1997; Takayama et al., 1998) while in the second analysis of 24 CPPSE accessions (Pagliarini et al., 2001) six were diploids. These results have implications for breeding programs and shed some more light on the genetic structure of this important grass genus. 
Table 3 - Number of microsporocytes analyzed and the percentage of cells with meiotic abnormalities.

\begin{tabular}{|c|c|c|c|c|c|c|c|c|c|c|c|}
\hline \multirow[t]{2}{*}{ Paspalum species } & \multirow[t]{2}{*}{ Accession number } & \multirow[t]{2}{*}{$2 n$} & \multirow{2}{*}{$\begin{array}{l}\text { N. of } \\
\text { PMCs }\end{array}$} & \multicolumn{8}{|c|}{ Phases of meiosis* } \\
\hline & & & & M I & A I & T I & P II & M II & A II & T II & Tetr. \\
\hline P. coryphaeum & BRA-000841 & 20 & 2172 & 4.89 & 3.09 & 0.55 & 6.25 & 2.91 & 1.88 & 0.60 & 0.40 \\
\hline P. lividum & BRA-006378 & 40 & 2096 & 5.86 & 71.92 & 42.85 & 36.36 & 76.92 & 45.45 & 37.83 & 56.39 \\
\hline P. notatum & BRA-006513 & 40 & 2015 & 1.50 & 1.85 & 0.78 & 1.39 & 2.63 & 2.50 & 0.89 & 1.26 \\
\hline P. notatum & BRA-008028 & 40 & 2066 & 55.77 & 86.44 & 51.89 & 47.93 & 30.00 & 75.00 & 44.30 & 34.78 \\
\hline P. conspersum & BRA-010260 & 60 & 2078 & 35.91 & 57.14 & 1.78 & 5.38 & 3.22 & 3.84 & 9.28 & 8.04 \\
\hline P. usterii & BRA-022624 & 40 & 2004 & 37.93 & 39.13 & 10.76 & 15.18 & 17.20 & 13.18 & 15.90 & 14.28 \\
\hline P. compressifolium & BRA-013102 & 40 & 2003 & 84.09 & 87.50 & 56.57 & 34.48 & 90.47 & 57.14 & 54.05 & 51.33 \\
\hline P. compressifolium & BRA-011282 & 40 & 2110 & 83.87 & 75.03 & 30.00 & 27.77 & 12.50 & 50.00 & 59.61 & 50.00 \\
\hline P. compressifolium & BRA-009105 & 40 & 2198 & 20.29 & 26.49 & 15.17 & 37.29 & 10.59 & 29.57 & 16.07 & 26.84 \\
\hline P. compressifolium & BRA-011304 & 40 & 2061 & 35.96 & 41.75 & 43.45 & 40.34 & 29.17 & 26.42 & 44.65 & 38.04 \\
\hline P. atratum & BRA-009661 & 40 & 2255 & 75.00 & 84.84 & 83.67 & 71.69 & 98.36 & 94.33 & 72.72 & 67.88 \\
\hline P. plicatulum & BRA-008940 & 40 & 2064 & 89.04 & 69.32 & 66.00 & 43.54 & 27.33 & 29.12 & 55.25 & 30.10 \\
\hline P. plicatulum & BRA-006157 & 40 & 2000 & 44.96 & 43.33 & 22.22 & 43.57 & 37.57 & 38.81 & 26.74 & 41.58 \\
\hline P. plicatulum & BRA-009784 & 40 & 2060 & 86.15 & 84.21 & 68.00 & 80.00 & 69.23 & 88.88 & 52.00 & 54.44 \\
\hline P. rrhodopedum & BRA-006602 & 40 & 2001 & 23.21 & 31.58 & 16.88 & 27.25 & 48.43 & 12.00 & 3.11 & 3.46 \\
\hline P. rhodopedum & BRA-006670 & 40 & 2035 & 65.62 & 60.00 & 58.51 & 51.35 & 31.81 & 88.23 & 43.39 & 56.73 \\
\hline P. limbatum & BRA-012530 & 40 & 2084 & 33.80 & 52.75 & 43.70 & 46.37 & 30.77 & 46.75 & 55.48 & 54.98 \\
\hline P. limbatum & BRA-009008 & 40 & 2167 & 20.68 & 85.71 & 11.11 & 13.43 & 5.26 & 95.23 & 4.91 & 0.63 \\
\hline Paspalum sp & BRA-008486 & 40 & 2083 & 29.75 & 21.67 & 17.00 & 5.30 & 34.04 & 21.28 & 17.80 & 26.31 \\
\hline Paspalum sp & BRA-008630 & 40 & 2000 & 48.63 & 49.18 & 24.13 & 24.11 & 76.92 & 70.00 & 16.75 & 7.60 \\
\hline Paspalum sp & BRA-008648 & 40 & 2301 & 27.38 & 58.27 & 38.88 & 29.07 & 68.97 & 77.78 & 30.23 & 22.67 \\
\hline Paspalum sp & BRA-008656 & 40 & 2127 & 33.23 & 19.68 & 18.30 & 8.52 & 65.66 & 69.64 & 7.25 & 27.27 \\
\hline Paspalum sp & BRA-008672 & 40 & 2060 & 73.00 & 52.00 & 55.00 & 69.00 & 62.00 & 79.00 & 60.00 & 59.00 \\
\hline Paspalum sp & BRA-008940 & 40 & 2064 & 89.04 & 69.32 & 66.00 & 43.54 & 27.33 & 29.12 & 65.25 & 40.10 \\
\hline Paspalum sp & BRA-009393 & 40 & 2021 & 45.78 & 40.28 & 25.09 & 48.57 & 43.10 & 45.51 & 46.81 & 50.93 \\
\hline Paspalum sp & BRA-010243 & 40 & 2073 & 46.17 & 47.10 & 68.72 & 59.12 & 28.12 & 44.00 & 73.00 & 56.17 \\
\hline Paspalum sp & BRA-011053 & 40 & 2071 & 16.57 & 22.22 & 32.53 & 24.82 & 16.53 & 27.65 & 37.29 & 38.37 \\
\hline Paspalum sp & BRA-011266 & 40 & 2010 & 76.23 & 26.86 & 52.36 & 29.89 & 41.76 & 41.50 & 28.91 & 37.68 \\
\hline Paspalum sp & BRA-012521 & 40 & 2010 & 76.72 & 89.28 & 76.11 & 38.84 & 90.08 & 89.08 & 90.69 & 88.54 \\
\hline Paspalum sp & BRA-012751 & 40 & 2002 & 52.40 & 63.94 & 61.57 & 57.19 & 59.26 & 59.56 & 52.30 & 65.19 \\
\hline Paspalum sp & BRA-013404 & 40 & 2128 & 41.10 & 30.66 & 26.90 & 20.63 & 43.60 & 27.59 & 18.57 & 13.9 \\
\hline Paspalum sp & BRA-013609 & 40 & 2000 & 73.95 & 69.39 & 56.23 & 21.05 & 77.91 & 62.20 & 51.11 & 63.66 \\
\hline Paspalum sp & BRA-014770 & 40 & 2069 & 20.85 & 74.22 & 52.82 & 46.40 & 37.40 & 74.63 & 53.26 & 47.78 \\
\hline Paspalum sp & BRA-009636 & 40 & 2123 & 71.42 & 90.90 & 33.33 & 29.06 & 71.42 & 87.50 & 26.26 & 21.96 \\
\hline Paspalum sp & BRA-013951 & 40 & 2011 & 58.01 & 37.07 & 28.99 & 12.50 & 75.00 & 42.45 & 32.87 & 28.23 \\
\hline Paspalum sp & BRA-008681 & 40 & 2251 & 48.01 & 39.56 & 14.53 & 14.18 & 26.92 & 7.14 & 16.25 & 23.88 \\
\hline Paspalum sp & BRA-011517 & 40 & 2409 & 82.35 & 88.88 & 51.68 & 66.44 & 70.83 & 72.07 & 43.33 & 59.99 \\
\hline
\end{tabular}

$* \mathrm{M}=$ metaphase, $\mathrm{A}=$ anaphase, $\mathrm{T}=$ telophase, $\mathrm{Tetr}=$ tetrad.

\section{References}

Adamowski EV, Pagliarini MS and Batista LAR (1998) Chromosome elimination in Paspalum subciliatum (Notata group). Sex Plant Reprod 11:272-276.

Adamowski EV, Pagliarini MS and Batista LAR (2000) Chromosome number and microsporogenesis in Paspalum maritimum (Caespitosa group, Gramineae). Braz Arch Biol Technol 43:301-305.
Batista LAR, Godoy RE and Pereira JM (1995) Potencial forrageiro de acessos de germoplasma do gênero Paspalum. Ensaio 1993/94. In: XXXI Reunião Anual da Sociedade Brasileira de Zootecna, Anais, Brasília, DF, pp 62-64.

Bonilha JR and Quarín CL (1997) Diplosporous and aposporous apomixis in a pentaploid race of Paspalum minus. Plant Sci 127:97-104.

Brown WV (1950) A cytological study of Texas Gramineae. Bull Torrey Bot Club 77:63-76. 
Burson BL (1975) Cytology of some apomictic Paspalum species. Crop Sci 15:229-232.

Burson BL (1991) Homology of chromosomes of the genomes in common and Uruguayan dallisgrass, Paspalum dilatatum. Genome 34:950-953.

Burson BL (1997) Apomixis and sexuality in some Paspalum species. Crop Sci 37:1347-1351.

Burson BL and Bennett HW (1971) Chromosome numbers, microsporogenesis, and mode of reproduction of seven Paspalum species. Crop Sci 11:292-294.

Burson BL, Voigt PW and Evers GW (1991) Cytology, reproductive behavior, and forage potential of hexaploid dallisgrass biotypes. Crop Sci 31:636-641.

Burton GL (1940) A cytological study of species in genus Paspalum. J Agric Res 60:193-197.

Chase A (1929) The North American species of Paspalum. Contributions from the United States National Herbarium 28:1310 .

Davidse G and Pohl RW (1972) Chromosome numbers and notes on some Central American grasses. Can J Bot 50:273-283.

Denham SS, Zuloaga FO and Morrone O (2002) Systematic revision and phylogeny of Paspalum subgenus Ceresia (Poaceae, Panicoideae, Paniceae). Ann Missouri Bot Gard 99:89-94.

Fernandes MIBM, Barreto IL, Salzano FM and Sacchet MCF (1974) Cytological and evolutionary relationships in Brazilian forms of Paspalum (Gramineae). Caryologia 27:455465.

Forbes I and Burton GL (1961) Cytology of diploids, natural and induced tetraploids and intraspecies hybrids of bahiagrass, Paspalum notatum Fluegge. Crop Sci 1:402-406.

Freitas PM, Takayama SY, Pagliarini MS and Batista LAR (1997) Evaluation of meiotic behavior in polyploid accessions of Paspalum (Plicatula Group). Nucleus 40:47-52.

Gould FW (1958) Chromosome number in southwestern grasses. Amer J Bot 45:757-767.

Gould FW (1968) Chromosome numbers of Texas grasses. Can J Bot 46:1315-1325.

Honfi AI, Quarín CL and Valls JFM (1990) Estudios cariológicos em gramíneas Sudamericanas. Darwiniana 30:87-94.

Katayama T and Ikeda H (1975) Cytogenetic studies on Paspalum distichum L. Cytologia 40:759-764.

Mehra PN and Chaudhary JD (1981) Male meiosis in some grasses of the tribe Paniceae from North Eastern India. I. Genus Paspalum. Cytologia 46:265-278.

Norrmann GA, Quarín CL and Burson BL (1989) Cytogenetics and reproductive behavior of different chromosome races in six Paspalum species. J Hered 80:24-28.

Nuñez O (1952) Investigaciones cariossistemáticas de las gramineas argentinas de la tribus Paniceae. Rev Fac Agron 28:229-256.

Pagliarini MS, Freitas PM, Takayama SY and Batista LAR (1998) An original meiotic mutation in Paspalum regnellii. Sex Plant Reprod 11:17-21.

Pagliarini MS, Takayama SY, Freitas PM, Carraro LR, Adamowski EV and Batista LAR (1999) Failure of cytokinesis and 2n gamete formation in Brazilian accessions of Paspalum. Euphytica 108:129-135.
Pagliarini MS, Freitas PM and Batista LAR (2000) Chromosome stickiness in meiosis of a Brazilian Paspalum accession. Cytologia 65:289-294.

Pagliarini MS, Carraro LR, Freitas PM, Adamowski EV, Batista LAR and Valls JFM (2001) Cytogenetic characterization of Brazilian Paspalum accessions. Hereditas 135:27-34.

Pozzobon MT and Valls JFM (1997) Chromosome number in germplasm accessions of Paspalum notatum (Gramineae). Braz J Genet 20:29-34.

Pozzobon MT, Valls JFM and Santos S (2000) Contagens cromossômicas em espécies brasileiras de Paspalum L. (Gramineae). Acta Bot Bras 14:151-162.

Quarín CL (1977) Recuentos cromossomicos in Gramineae de Argentina subtropical. Hickenia 1:73-78.

Quarín CL (1992) The nature of apomixis and its origin in Panicoid grasses. Apomixis Newsllet 5:7-15.

Quarín CL and Hanna WW (1980) Chromosome behavior, embryo sac development, and fertility of Paspalum modestum, $P$. boscianum, and $P$. conspersum. J Hered 71:419-422.

Quarín CL and Burson BL (1991) Cytology of sexual and apomictic Paspalum species. Cytologia 56:223-228.

Quarín CL and Norrmann GA (1987) Cytology and reproduction behavior of Paspalum equitans, $P$. ionanthum and their hybrids with diploid and tetraploid cytotypes of $P$. cromyorrhizum. Bot Gaz 148:386-391.

Quarín CL, Pozzobon MT and Valls JFM. (1996) Cytology and reproductive of diploid, tetraploid and hexaploid germplasm accessions of a wild forage grass: Paspalum compressifolium. Euphytica 90:345-349.

Quarín CL, Valls JFM and Urbani MH (1997) Cytological and reproductive behaviour of Paspalum atratum, a promising forage grass for the tropics. Trop Grass 131:114-116.

Quarín CL, Norrmann GA and Espinoza F (1998) Evidence for autoploidy in apomictic Paspalum rufum. Hereditas 129:119-124.

Reeder JR (1967) Notes on Mexican grasses. VI. Miscellaneous chromosome numbers. Bull Torrey Bot Club 94:1-17.

Snyder LA (1953) Breeding and evaluation of forage grasses. Grass cytology. Report Fed Exp Sta Mayagnez P.R. pp 18.

Sybenga J (1996a) Chromosome pairing affinity and quadrivalent formation in polyploids: Do segmental allopolyploids exist? Genome 39:1176-1184.

Takayama SY, Freitas PM, Pagliarini MS and Batista LAR (1998) Chromosome number in germplasm accessions of Paspalum (Plicatula group) from different regions of Brazil. Euphytica 99:89-94.

Tischler CR and Burson BL (1995) Evaluating different bahiagrass cytotypes for heat tolerance and leaf epicuticular wax content. Euphytica 84:229-235.

Urbani MH, Quarín CL, Espinoza F, Penteado MIO and Rodrigues IF (2002) Cytogeography and reproduction of the Paspalum simplex polyploid complex. Plant Syst Evol 236:99-105.

Venuto BC, Burson BL, Hussey MA, Redfearn DD, Wyatt WE and Brown LP (2003) Forage yield, nutritive value, and grazing tolerance of dallisgrass biotypes. Crop Sci 43:295301.

Associate Editor: Marcelo Guerra 